Review

\title{
LIVESTOCK MANURE COMPOSTING IN COLD REGIONS: CHALLENGES AND SOLUTIONS
}

\author{
YOUSIF ABDELRAHMAN YOUSIF ABDELLAH, CHUNYAN LI*
}

College of Resources and Environment, Northeast Agricultural University, Harbin, People's Republic of China

ABDELLAH, Y.A.Y. - LI, CH.: Livestock manure composting in cold regions: Challenges and solutions. Agriculture (Pol’nohospodárstvo), vol. 66, no. 1, pp. 1-14.

\begin{abstract}
This review investigates the significant challenges of the process of livestock manure composting in cold regions and assesses the critical features related to the quality of the final compost product. Recently, the composting process has grasped more attention because of environmental pollution concerns and seeks for environmentally-sound approaches for managing livestock manure. Despite recent progress in crucial areas like the microbiology of compost, further improvement is needed in composting process monitoring. Therefore, specific obstacles related to livestock manure composting in cold regions, such as the generation and preservation of temperature, and the solution of obstacles such as inoculation of coldadapted microorganisms, and the role of biochar in prolonging the thermophilic stage of composting were reviewed. Also, the challenges were adequately addressed, and promising strategies to improve composting of livestock manure under harsh conditions were proposed. Still, there is a need for more investigation to get a better understanding of the role of microbial inoculants and biochar amendment regarding the start-up of the composting process in cold regions.
\end{abstract}

Key words: manure composting, cold-adapted microorganisms, biochar, low-temperature

\section{INTRODUCTION}

Livestock manure refers to animal excreta (urine and faeces) and bedding materials, which used as organic fertilisers for agricultural purposes ( $\mathrm{He}$ et al. 2016). Depending on the specific livestock management system, livestock manure may also include discarded feed, casings, soil, and water. From the launching of agricultural practices before 80 centuries ago in Neolithic Europe, livestock manure has become an integral part of sustainable agricultural production (Bogaard et al. 2013; Pratt et al. 2014; He et al. 2016). Before the widespread production of synthetic fertilisers, most of the exogenous crop nutrients came from animal manure (He et al. 2016; Loyon 2017). Manure nutrient contents are natural elements that eventually contribute to plant production. These nutrients are suitable for recycling in the natural environment (Horn et al. 1994). In some countries, the treated manure applied in the soil for agricultural purposes was decreased obviously (Kováčik et al. 2016). Whereas, in other countries, a considerable amount of manure was produced more than can be cost-effectively brought to the farmland. Therefore, the production and treatment of livestock manure have an impact on the environment beyond the scope of simple organic fertiliser (Horn et al. 1994; He et al. 2016). Accordingly, the

Dr. Yousif Abdelrahman Yousif Abdellah, Prof. Chunyan Li, PhD. (*Corresponding author), College of Resources and Environment, Northeast Agricultural University, Harbin, 150030 Heilongjiang, People's Republic of China. E-mail: chunyanli@neau.edu.cn; ayousyf@yahoo.com 
amount of livestock manure that can be used for agricultural application as an organic fertiliser can vary widely between and within countries.

Most livestock production in cold regions is situated between temperate and polar areas, where the annual average surrounding temperature is usually lower than $8.0^{\circ} \mathrm{C}$ (Yao et al. 2019). Inadequate management of the large volumes of livestock manure in these regions was recognized to cause water pollution and eutrophication by leaching of nitrate, phosphorus, ammonia emissions in addition to air pollution by greenhouse gas (GHG) and ammonia $\left(\mathrm{NH}_{3}\right)$ emissions (Philippe \& Nicks 2015; Loyon 2017; Subbotin et al. 2017). These pollutants not only harm the quality of air, surface water, soil, and groundwater but also pose a threat to public health (Hu et al. 2017).

Pratt et al. (2014) mentioned some aspects that have sparked increased emphasis on applicable management of manure such as

I. Tightening of regulations on nutrient leaching,

II. Improved awareness of the adverse environmental impacts of manure gaseous emissions especially nitrous oxide, methane, and ammonia, and

III. Escalating costs of synthetic and mineral fertilisers combined with dwindling and non-renewable natural deposits.

Among many livestock manure management methods, compost has been widely concerned because of its low operating cost, high social and environmental benefits. Other benefits of composting include reducing direct manure use, destroying weed seeds and pathogens (Xiao et al. 2017; Wei et al. 2020). Therefore, composting is strongly recommended for the treatment of manure (Wei et al. 2017; Gou et al. 2017; Li et al. 2019; Cui et al. 2020).

Composting is a complex biochemical process, which relies on the interaction of highly diverse microbial communities to transform organic waste into nutrient-rich, safe and stable organic fertiliser (Li et al. 2019; Hou et al. 2017); this process can be completed under aerobic or anaerobic conditions. Aerobic composting is the breakdown of organic substances in the presence of oxygen, which is usually achieved by providing air supply. The main product of aerobic metabolism is microbial biomass, carbon dioxide, water, and heat (Williams \& Marks 1991). On the contrary, the anaerobic process is the biological decomposition without oxygen, which produces methane, carbon dioxide, and organic acid metabolites (Williams \& Marks 1991). The aerobic composting process can stabilize the organic matter during the composting; reduce the adverse effects of indigenous microbes, and the impact of relatively veterinary pharmaceuticals in the final compost product (Gou et al. 2017; Onwosi et al. 2017; Li et al. 2019; Zhu et al. 2020). Therefore, the aerobic process is a widely applied for degradation and transformation of organic matter, and recovery of mineral nutrients such as nitrogen, phosphorus, and potassium that can be used by plants (Onwosi et al. 2017). Various composting technologies currently used include windrows, aerated or static bins, and in-vessel systems (Akdeniz 2019).

The treatment of livestock manure varies with seasons. The weather has a significant impact on manure application strategies, and winter manure treatment brings additional considerations because of snow cover, winter precipitation, frozen soil, and winter melting. The low-temperature environment poses a significant technical challenge to the efficient operation of composting facilities in cold areas (Wang et al. 2013; Yao et al. 2019). Margesin et al. (2006) stated the adverse effects of snowfall on composting operations such as oxygen supply and compost water content and the impact of the vast frozen zones on the inactivation efficiency of pathogenic microorganisms.

Up to this point, this review was accomplished to provide a comprehensive evaluation of previous reports on the composting process in cold regions. A large number of articles discussed the composting process under middle and high temperatures; however, there is little information about the challenges encountered in composting under cold conditions. Here, this review attempted to emphasize these bottlenecks in the composting process in cold areas and to explain the main stages to improve the composting process. Therefore, the main parts of focus are presented as follows: (a) general challenges in manure composting in cold regions; (b) strategies used to accomplish the composting process in cold regions; (c) composting process monitoring chal- 
lenges in cold regions; (d) microbiology in livestock manure composting under cold conditions; and (e) compost quality assessment in cold regions.

\section{GENERAL CHALLENGES IN MANURE COMPOSTING IN COLD REGIONS}

\subsection{Livestock-producing regions with cold climate}

The areas with cold weather commonly have an average annual air temperature of less than $8.0^{\circ} \mathrm{C}$ (Yao et al. 2019; Stempvoort \& Biggar 2008). The weather in these areas is characterized by cool and humid spring and fall, dry summer, and cold winter. Additionally, in parts with an average temperature higher than $8.0^{\circ} \mathrm{C}$, the fluctuation of daily temperature may still experience a substantial interval of subzero temperatures (Yao et al. 2017). Most countries with a cold climate such as Canada, China, Finland, Iceland, Norway, Poland, Russia, Sweden, and the USA are in the northern hemisphere (Yao et al. 2019). These countries are located in areas ranging from temperate to polar zones. In the north of Europe, the climate is also known for the harsh winter, where the temperature can reach $-27^{\circ} \mathrm{C}$. Because of the warm Gulf Stream, the atmosphere in the northern European countries is much milder than in countries of similar latitudes in Asia and the United States (Minobe et al. 2008).

Countries like China and the USA have more variable climate conditions. In the USA, for example, the winter in the southern states is mostly mild. In contrast, the northern states are much colder, with heavy snowfall and temperatures below $0^{\circ} \mathrm{C}$ (Bucchignani et al. 2014). In China, areas in the north of the isotherm across the Huaihe River, Qinling Mountain, southeast Qinghai, and Tibet Plateau have temperatures below $0^{\circ} \mathrm{C}$, and the temperature of the southern areas are higher than $0^{\circ} \mathrm{C}$ (Bucchignani et al. 2014; Yao et al. 2019). In winter, the temperature in Heilongjiang Province can reach an average of $-30^{\circ} \mathrm{C}$, while the temperature in Hainan Province is above $20^{\circ} \mathrm{C}$. The climate conditions in Russia also vary significantly due to the country's immense size, while the average temperature is $-5.5^{\circ} \mathrm{C}$ (Yao et al. 2019; Blinnikov 2011).

\subsection{Livestock manure composition in cold regions}

The quantity of generated manure varies according to the sort of livestock diet, age, productivity, and other factors. In the cold areas, such as altiplano, livestock diet is not the same with that in warm regions, which resulted in the characteristics of manure (low moisture content, protein, and high content of recalcitrant compounds, and lignin) (Yao et al. 2019). Large livestock farms are overgrowing, producing a large amount of wet manure, which comprises vast volumes of different nutrients, antibiotic resistance genes, heavy metals, and pathogens (Li et al. 2018). In cold regions, the manure amount varies from 60 to $85 \mathrm{~kg}$ (wet basis) per $1,000 \mathrm{~kg}$ of livestock mass per day in large livestock farms (Engler 1999; Yao et al. 2019). Unfortunately, the world production of livestock manure does not spatially parallel with proper weather circumstances for manure treatment. When surrounding temperatures drop under $20^{\circ} \mathrm{C}$, the treatment process becomes slower (Yao et al. 2019).

\subsection{Livestock manure management in cold regions}

Livestock manure management, incorporating production, collection, storage, treatment, transfer, and utilization, is a significant factor for sustainable livestock production. It is a complicated procedure, including the concerns of environmental regulations, economic restrictions, agronomic circumstances, social and health matters (Yao et al. 2019). Manure management is crucial to reduce nutrients loss to water sources, decrease gas emissions, reduce the pathogenic microbes, and xenobiotic compounds (emerging pollutants) (Loyon 2017). Therefore, to develop a cost-effective and rapid treatment method of vast volumes of manure, Horn et al. (1994) stated that the approach of livestock manure management should include the following principal contents:

I. Manure production and classification,

II. Environmental factors,

III. Modes for processing and resource recovery,

IV. Optimization of method options.

Manure has an excellent nutrient rate. Nitrogen often exists in livestock manure as an inorganic form (ammonium), which is readily available to plant. However, due to the low natural transformation rate in cold areas, excessive application of ma- 
nure may lead to an increase of phosphorus, potassium, and other nutrients to unacceptable levels. In the long term, the high manure application rates are unsustainable (Yao et al. 2019); therefore, the best manure management approach should be planned to decrease the harmful environmental impact (Horn et al. 1994). There are several technical choices to reduce the influence of manure production on the environment in cold regions. Either thermochemical or biological methods can be applied to dispose of livestock manure (Yao et al. 2019). The summary of manure management methods is displayed in Table 1. Among these methods, composting is considered the best way to deal with manure, as other methods such as anaerobic digestion process characterized by insufficient mass transfer, inhibitor accumulation such as volatile fatty acids and ammonia, while the biological nitrogen removal process characterized by the slow growth of anammox organisms, long start-up time, and risk of biomass inhibition (Zubair et al. 2020). Meanwhile, the disadvantage of membrane filtration and solid-liquid separation is that only the suspended solids more massive than the sieve could be removed, so the manure after filtration shows higher anaerobic biodegradability (Rico et al. 2011). Also, manure management approach such as fermentation of livestock manure by larvae of a housefly to shorten the manure storage duration (Kováčik et al. 2010), was less frequently used (Loyon 2017). For these reasons, composting is an optimum solution for livestock manure in cold regions. The composting process allows the safe storage and transfer of manure and improves the value of compost products. In addition, compost product is a more concentrated and stable product than livestock manure, which can be quickly and equally dis-

$\mathrm{T}$ a b 1 e 1

Summary of livestock manure management approaches in cold regions (Yao et al. 2019)

\begin{tabular}{|c|c|}
\hline Methods & Descriptions \\
\hline Composting & $\begin{array}{l}\text { - Aerobic biological decomposition and stabilization processes that convert the solid } \\
\text { manure into compost. } \\
\text { Types: passive aeration, windrow/mechanical agitation, forced aeration/aerated static } \\
\text { pile, in-vessel systems. } \\
\text { - Inactivation of weed seeds and some pathogens. } \\
\text { Composted manure is less susceptible to leaching and further ammonia losses. The } \\
\text { compost is sufficiently stable for storage and subsequent soil application. }\end{array}$ \\
\hline Anaerobic digestion & $\begin{array}{l}\text { - Include a series of biological processes in which microorganisms break down organic } \\
\text { substances of manure in the absence of oxygen. } \\
\text { Produce a mixture of gases (mainly methane and carbon dioxide) that can be used as } \\
\text { bioenergy. }\end{array}$ \\
\hline Biological nitrogen removal & $\begin{array}{l}\text { - Biological conversion of ammonium to inert nitrogen gas using classical nitrogen removal } \\
\text { treatment. } \\
\text { - Combine autotrophic nitrification and heterotrophic denitrification processes. } \\
\text { - The feedstock is generally the liquid fractions separated from slurry. }\end{array}$ \\
\hline Membrane filtration & $\begin{array}{l}\text { - Removal of suspended solids (SS), colloids, bacteria, and nutrients from a liquid through } \\
\text { membrane filtration. } \\
\text { Require manure pre-treatments to prevent fouling, maximize membrane life, and increase } \\
\text { flux. }\end{array}$ \\
\hline Acidification & $\begin{array}{l}\text { - Application of acidic reagents such as sulfuric acid to manure slurry to lower its } \mathrm{pH} \text {. } \\
\text { - } \quad \text { Reduce ammonia emissions and deactivate pathogens. }\end{array}$ \\
\hline Combustion/ incineration & $\begin{array}{l}\text { - Complete the thermochemical oxidation of organic matter in manure to obtain recoverable } \\
\text { heat, ashes, and gasses. } \\
\text { - For manure with high moisture content, the pre-drying process is generally required to } \\
\text { reduce moisture content. }\end{array}$ \\
\hline Thermal concentration & $\begin{array}{l}\text { - } \quad \text { Reduce the moisture content of manure by external heating. } \\
\text { - } \quad \text { Concentrate nutrients ion to reduce transportation costs. }\end{array}$ \\
\hline Solid-liquid separation & $\begin{array}{l}\text { - Separate manure slurry into a solid and liquid fraction. } \\
\text { - Types: sedimentation and mechanical separation. } \\
\text { - } \quad \text { The relative simplicity of the process and low costs of the equipment involved. }\end{array}$ \\
\hline
\end{tabular}


tributed in farmland (Bernal et al. 2009). The benefits of composting livestock manure compared with the direct application can be reviewed in:

1. Reduction of volume and moisture;

2. Removal and control of odours;

3. Elimination of pathogens and weeds;

4. Microbial stabilization;

5. Production of high-value fertiliser or product;

6. The simplicity of storage, transport, and use.

Specific physicochemical characteristics of livestock manure are insufficient for composting, which may limit the efficiency of a composting process such as high water content, low porosity, high nitrogen concentration, low organic carbon concentration (low $\mathrm{C}: \mathrm{N}$ ratio), and in some cases, high $\mathrm{pH}$ value (Table 2). Therefore, it is necessary to carry out sufficient compost management to obtain high-quality compost (Bernal et al. 2009).

\section{STRATEGIES USED TO ACCOMPLISH THE COMPOSTING PROCESS IN COLD REGIONS}

\subsection{Compost reactor-heating approaches}

To ensure the regular operation of the composting process in cold areas, the methods of reactor heating were proposed (Sun et al. 2019). Under cold conditions, the performance of composting can be improved by implementing some strategies, such as reducing air supply, compensating biodegradable materials and reducing turning frequency (Wang et al. 2013), natural gas and biogas heating (Xu et al. 2010), winter cover cropping (Dabney et al. 2001), electric heating (Masse \& Masse 2001), and reactors wrapped by insulation cotton (Sun et al. 2019). The previously mentioned heating techniques seek at boosting the compost microbial activity under the low surrounding temperature circumstance. Nevertheless, these techniques are not energy saving or economical in the applied composing factory production (Xie et al. 2017).

\subsection{Inoculation approaches}

\subsubsection{Inoculation with cold-adapted microorgan- isms and their enzymes activities}

Due to the low activity of microorganisms under low temperature, the generation of heat energy is weak, and the composting temperature is difficult to increase. Therefore, in this case, without the microbial activity, the composting process cannot be completed (Xie et al. 2017). Inoculation is an effective way to control the composting process, which can accelerate and promote the maturity of the final compost products (Sun et al. 2017). Hence, different composting systems were inoculated with various exogenous microorganisms. For example, bacterial inoculants applied in pig manure composting to enhance nitrogen turnover, increase nitrogen content, and promote maturity (Jiang et al. 2015). Besides, inoculation with lactobacillus increased the temperature and accelerated the organic matter degradation in food waste composting (Tran et al. 2015). Moreover, inoculation with microbial agents promoted the aromatization of humic acid in the final

$\mathrm{T}$ a b 1 e 2

Average components of livestock slurry and manure [g/kg fresh weight] (Bernal et al. 2009)

\begin{tabular}{|l|r|c|c|c|}
\hline Livestock manure & Dry matter & Organic-C & Total-N & $\mathrm{NH}_{4}-\mathrm{N}$ \\
\hline Cattle $^{(\mathrm{L})}$ & $15.0-123.0$ & $3.8-36.0$ & $2.0-7.0$ & $1.0-4.9$ \\
Pig $^{(\mathrm{L})}$ & $4.9-152.0$ & $1.0-65.0$ & $0.6-7.8$ & $0.3-6.6$ \\
Poultry $^{(\mathrm{L})}$ & $10.0-367.0$ & $11.0-112.0$ & $2.0-21.0$ & $1.9-9.4$ \\
Cattle $^{(\mathrm{S})}$ & $140.0-300.0$ & $65.0-126.0$ & $4.2-8.1$ & $0.3-2.0$ \\
Pig $^{(\mathrm{S})}$ & $150.0-330.0$ & $42.0-132.0$ & $3.5-11.0$ & $0.5-6.0$ \\
Poultry $^{(\mathrm{S})}$ & $220.0-700.0$ & $103.0-597.0$ & $10.0-58.0$ & $2.4-18.0$ \\
\hline
\end{tabular}

${ }^{\mathrm{L}}$ - liquid manure/slurry; ${ }^{\mathrm{s}}-$ solid manure 
compost product (Wei et al. 2007). Consequently, inoculating compost with functional microbes can shorten the composting cycle and improve the quality of the final product. Nevertheless, most inoculants cannot acclimate to low-temperature circumstances, which limit the use of the inoculation approach in cold regions (Sun et al. 2017). Cold-adapted microorganisms can survive in a cold environment (Maayer et al. 2014); due to their adaptive capacity adjusting with cold stresses (Xie et al. 2017; Sun et al. 2017). These microorganisms divided into psychrophiles (with the optimum temperature at or below $15^{\circ} \mathrm{C}$ ) and psychrotolerant (optimum and maximum temperature above $25^{\circ} \mathrm{C}$ ) (Chaudhary \& Kim 2019). There are many cold-adapted microorganisms, which previously applied to the composting process. For example, Aeromonas sp. (Wang et al. 2013), Moraxella fulton sp., Kurthia sp., Klebsiella sp. (Hou et al. 2017) enhanced protein degradation during the composting process. The importance of cold-adapted microorganisms in composting is that they can grow in cold conditions. In the early stage of composting, these microorganisms (such as Clostridium vincentii, Iodobacter fluviatilis, Pseudomonas jessenii) can promote the degradation and transformation of the organic matter (Xie et al. 2017). When microorganisms were inoculated into composting, the improved biological input can provide additional long-term benefits for the application of compost products in farmland (Sánchez et al. 2017). Nevertheless, in a cold environment, a single microbial species is not enough, and inoculating consortia with mixed microbial species is a better approach (Chaudhary \& Kim 2019).

Generally, inoculating compost with low-temperature microorganisms is a feasible alternative method. However, there is still a risk of failure due to the typical adverse environmental conditions of the composting process. Therefore, it is considered that it is more suitable to inoculate compost with cold-adapted microorganisms isolated from compost mixture.

Microorganisms adapted to a cold environment inhabit in a natural and man-made cold climate, and play an essential role in the cycle of carbon and other nutrients (Saady \& Massé 2013). These microorganisms are significantly different from thermophilic microbes because they grow well at $15^{\circ} \mathrm{C}$ or lower, which is due to a particular cell membrane (Gou et al. 2017). The cold-active enzymes produced by cold-adapted microorganisms are of great significance in organic transformation during the composting process (Hou et al. 2017; Chaudhary \& Kim 2019). The organic transformation includes many biological oxidation processes, such as cellulolysis, proteolysis, and amylolysis, which are the key to rapid composting process (Awasthi et al. 2018), as the cold-active enzymes induced by the compost organic matter, that influence the metabolism of microorganisms followed by releasing heat and improving the temperature of the compost (Sun et al. 2017).

The applicability and practicability of microbes' enzyme activity determination in monitoring and characterizing of the composting process under cold conditions were reported (Margesin et al. 2006; Sun et al. 2017). These enzymes play an essential role in the process of organic matter degradation and transformation throughout composting ( $\mathrm{Xi}$ et al. 2016; Awasthi et al. 2017). The major cold-active enzymes include urease (UA), protease (PRT), $\beta$-glucosidases ( $\beta$-Glu), fluorescein diacetate (FDA) hydrolytic activity, cellulase, xylanase and invertase (IA) (Sun et al. 2017; Margesin et al. 2006). Every enzyme has a particular function in the composting process. For example, UA can degrade organic nitrogen into small nitrogen elements, which is beneficial to microbial growth. PRT contributes to protein converting into polypeptides and is related to bacterial biomass. Microorganisms generate $\beta$-Glu to breakdown cellobiose to glucose. IA is responsible for converting disaccharide into glucose and supporting direct energy for microbial metabolism (Sun et al. 2017). Cellulase and xylanase are essential enzymes in lignocellulose degradation process (Margesin et al. 2006).

\subsubsection{Biochar amendment in the composting process in cold regions}

Biochar, as a carbon-rich material obtained from biomass pyrolysis, is used as a soil improver in low fertility soil, which usually has a series of positive effects, including improving nutrient utilization, improving soil physical properties, interacting with different biogeochemical cycles, and increasing crop yield (Sanchez et al. 2018). In recent years, more at- 
tention has been paid to the application of biochar as a composting additive. The results showed that adding biochar in the initial stage of composting could improve the temperature and the quality of compost final products (Xiao et al. 2017; Guo et al. 2020). However, many factors can affect the role of biochar on the process of composting, such as the application amount, the feedstock and pyrolysis temperature, and the particle size. At the beginning of the composting process, a wide range of biochar rates $(3-50 \%)$ were usually applied (Sanchez et al. 2018), because biochar provides suitable habitat for microbial community, provide nutrition for their growth and stimulate their activities by strengthening compost air circulation (El-Naggar et al. 2019). Wei et al. (2014) reported that biochar addition could shorten the time of entering the thermophilic phase, increase the temperature $\left(56^{\circ} \mathrm{C}\right)$ and prolong the duration of the thermophilic stage. Similarly, Czekala et al. (2016) reported that the addition of biochar at a rate of $10 \%$ accelerated the emergence of the maximum daily compost temperature and resulted in the maximum observed temperature. Nevertheless, few papers have explored the impact of biochar amendment on manure composting in cold regions. For example, Liu et al. (2019) added different amounts of biochar in pig manure composting accomplished under $-5-10^{\circ} \mathrm{C}$, and the outcomes revealed added biochar significantly prolonged the thermophilic phase, and produced harmless compost product. The reported findings indicated that biochar has the potential to play a fundamental task in the enhancement of aerobic composting in cold areas.

Based on the impacts of biochar on facilitating the composting process in cold environments, there is an emergent need to elucidate the mechanisms and functions of biochar for promoting the composting process.

\section{COMPOSTING PROCESS MONITORING CHALLENGES IN COLD REGIONS}

\subsection{Temperature}

One of the potential benefits of studying the effects of low temperature on composting is to improve the general knowledge of composting processes as well as to increase the database on cold weather composting (Williams \& Marks 1991). Temperature is the environmental factor that plays a vital role in the stability of composting. In cold areas, the temperature below $0^{\circ} \mathrm{C}$ lasts for six months in a year, which is the main limiting parameter of compost maturity (Li et al. 2012; Xie et al. 2017; Sun et al. 2017; Wang et al. 2013). It takes 7 to 18 days for the compost mixture to reach $55^{\circ} \mathrm{C}$ at an ambient temperature of -17 to $0^{\circ} \mathrm{C}$, and 2 to 6 days at 9 to $17^{\circ} \mathrm{C}$ (Williams \& Marks 1991). Therefore, the low ambient temperature might drastically prolong the mesophilic period, shorten the thermophilic period, affect substance dried and compost maturity, and even cause in the failure of composting progression (Wang et al. 2013). The variation of compost temperature is the result of the energy balance between the rate of biological heat generation and the rate of heat loss to the ambiences (Wang et al. 2013). Due to the influence of thermal gradient on heat transfer rate, the significant temperature difference can accelerate the heat transfer of compost system to the surrounding environment (Hou et al. 2017), throughout CCR (conduction, convection, radiation) and water volatilization (Wang et al. 2013). As a result, it is of considerable significance to improve and maintain composting temperature for successful composting in cold areas (Sun et al. 2017; Xie et al. 2017). The energy balance is the role of numerous parameters involving the features of the composting mixtures (e.g. moisture content and readily biodegradable organics matter), the environmental circumstances (e.g., ambient temperature, air humidity, rainfall) along with the operational strategies (e.g. turning rate, aeration rate, a feature of the composting system) (Wang et al. 2013).

\subsection{Aeration rate}

Composting is an exothermic process, which increases the rate of microbial activity and affects the heat output. These coupled feedback processes effectively improve the temperature of the composting process, usually with adequate aeration (Williams \& Marks 1991). Proper oxygen supply is the most critical consideration in the composting process, so aeration is critical. Because the composting process is directly related to microbial population dynamics, the efficiency of the composting process is strongly affected by oxygen concentration 
(Cerda et al. 2018). The most common ventilation procedure in the composting process is to turn the compost mixture. This makes the compost mixture easy to be utilized by microorganisms, resulting in gas emissions (Onwosi et al. 2017). Ventilation also contributes to the promotion of aerobic conditions, thus facilitating faster aerobic metabolic pathways and rates related to aerobic processes (Williams \& Marks 1991). Although improving ventilation in the early stages of organic degradation can shorten the time of waste stabilization, excessive ventilation or turning can lead to the loss of essential components in the composting process (Onwosi et al. 2017).

\subsection{Moisture content}

Moisture content is necessary to support the microbial activities for the degradation and transformation of organic matter, and for the exchange of micronutrients throughout the microbial cell membrane (Reyes et al. 2018). It was suggested that the optimum moisture content of composting material is $50-60 \%$. Low moisture can inhibit microbial activity, and high moisture can affect the ventilation of the compost pile (Akdeniz 2019). Hence, maintaining proper moisture balance is a critical factor in the design of any other organic substrate composting system (Williams \& Marks 1991).

\section{4. $C / N$ ratio}

The mixing of different animal manure and bulking agents can promote the digestion process in the cold area by adjusting the $\mathrm{C} / \mathrm{N}$ ratio (Yao et al. 2019). Amending bulking agents rich in available $\mathrm{C}$, such as rice husk, wood chip, sawdust, and peanut shells (Onwosi et al. 2017), can decrease nitrogen losses in the form of ammonia throughout the composting of agricultural residues with high nitrogen content (Bernal et al. 2009). The $\mathrm{C} / \mathrm{N}$ ratio is critical for the growth of microorganisms during composting since it delivers the carbon and nitrogen source needed for growth (Onwosi et al. 2017; Cerda et al. 2018). The commonly recommended rate of the $\mathrm{C} / \mathrm{N}$ ratio in compost mixture is between 25 and 30 (Reyes et al. 2018), although the initial $\mathrm{C} / \mathrm{N}$ ratio of $20-40: 1$ has frequently given appropriate composting products (Onwosi et al. 2017). The $\mathrm{C} / \mathrm{N}$ ratio is a measure of the decomposition degree owing to the degradation of carbon to $\mathrm{CO}_{2}$ during the high-rate degradation stage. Then, the $\mathrm{C} / \mathrm{N}$ ratio decreases throughout the composting process because the $\mathrm{C}$ degradation rate is higher than the mineralization rate of $\mathrm{N}$. Thus, an excessive $\mathrm{C} / \mathrm{N}$ relates to a deficiency of nutrients to microbial communities, and a low $\mathrm{C} / \mathrm{N}$ ratio implies the release of several undesirable compounds such as odours or salts (Onwosi et al. 2017; Cerda et al. 2018).

As explained above, there are various challenges in cold regions to make the composting process a cost-effective technology, with a shorter time and with proper compost final product characteristics. Such a compost product may contribute to decreasing not only the massive volumes of livestock manure but also to reduce a wide range of manure materials and pathogens that may otherwise instigate serious environmental drawbacks if not appropriately managed.

\section{MICROBIOLOGY IN LIVESTOCK MA- NURE COMPOSTING UNDER COLD CONDITIONS}

\subsection{Microbial communities during composting un- der cold conditions}

Composting is a process regulated by various microbial activities (Saludes et al. 2007), through the degradation of organic matter and the improvement of compost quality (Zhang et al. 2018). The biological characteristics of composting require understanding the key factors that affect the microbial ecosystem to achieve the best composting process (Saludes et al. 2007). The change of the microbial community during composting indicated the influence of mixed psychrophilic microbes on the composting process (Hou et al. 2017). A series of different microbial communities were observed during composting, which varies according to the main physical and chemical conditions of different composting stages (Onwosi et al. 2017). Long-term acclimatization of the active psychrophilic microbial community is essential for the effective treatment of livestock manure in cold areas (Yao et al. 2019). To clarify the structure and dynamics of microbial communities during composting, some reports focused on the metabolic activities of these microorganisms and their interactions with carbon, nitrogen transformation, and organic matter composition 
(Wang et al. 2016; Liu et al. 2018). Nevertheless, the effect of unique composting procedures on microbial communities requires more investigation. Proper management of process parameters, such as temperature, water content, texture, and oxygen, determines the sequence of microorganisms, thereby resulting in high-quality compost product (Liu et al. 2018). Different investigations evaluated the effect of environmental parameters on microbial communities' diversity in the composting process. For example, Xi et al. (2016) found that the variety of humic acid-reducing microorganisms was significantly related to dissolving organic carbon, total nitrogen, and germination index. Besides, it was reported that microbial communities' successions are shaped by the evaluation of compost physicochemical parameters, like the $\mathrm{C} / \mathrm{N}$ ratio, $\mathrm{pH}$, and electrical conductivity. In addition, temperature fluctuation has a significant effect on microbial communities during the composting process (Liu et al. 2018).

\subsection{New analytical tools}

Composting is a biochemical process that accomplished by different types of fungi, and bacteria. It is also described as a solid-state fermentation ac- tivity (Onwosi et al. 2017). Many studies have used the methods of dependent culture and independent culture to analyze the structure of the compost microbial community (Table 4). The detection of microbial diversity in the composting process by culture separation technique was used for a long time (Beffa et al. 1996; Ryckeboer et al. 2003; Nakamura et al. 2004). However, these methods could not entirely explain the microbial community structure and diversity throughout various composting phases due to culture medium restrictions (Liu et al. 2018). Moreover, the above methods were used to isolate and culture microorganisms on solid media, which they can only give a selective observation of the composting process. Nevertheless, microbes own unique growth systems, and many of them are not cultured that makes the process biased (Awasthi et al. 2019). For that reason, the culture-independent methods such as the determination of adenosine triphosphate (ATP), microbial activity, and the potential metabolic capacity measured by a Biolog single carbon utilization test were proposed (Cerda et al. 2018). Culture-independent approaches were applied to make the process simpler and not complicated, to grasp the action and activities of the mi-

T a b 1 e 3

Summary of some cold-adapted microorganisms detected during the composting process

\begin{tabular}{|c|c|c|c|}
\hline Detected microorganisms & Type & Identification method & References \\
\hline $\begin{array}{l}\text { Brevundimonas diminuta } \mathrm{CB} 1 \text { and } \\
\text { Flavobacterium glaciei } \mathrm{CB} 23\end{array}$ & bacteria & Isolation in Petri dishes & Gou et al. (2017) \\
\hline $\begin{array}{l}\text { Flavobacterium glaciei } \\
\text { Kurthia } \mathrm{sp} . \\
\text { Moraxella fulton } \mathrm{sp} . \\
\text { Klebsiella } \mathrm{sp} . \\
\text { Pseudomonas sp. } \\
\text { Morganella } \mathrm{sp} . \\
\text { Burkholderia } \mathrm{sp} .\end{array}$ & bacteria & $\begin{array}{l}\text { PCR and high-throughput } \\
\text { sequencing (HTPS) }\end{array}$ & Hou et al. (2017) \\
\hline Aeromonasa sp. & bacteria & Isolation in Petri dishes & Wang et al. (2013) \\
\hline $\begin{array}{l}\text { Psychrobacter sp. b110-1, Arthrobacter sp. } \\
\text { TSBY-50, Psychrobacter pulmonis strain } \\
\text { LMG } 1012 \text { and Arthrobacter sp. G8 }\end{array}$ & bacteria & $\begin{array}{l}\text { PCR-denaturing gradient gel } \\
\text { electrophoresis PCR-DGGE } \\
\text { fingerprint }\end{array}$ & Sun et al. (2017) \\
\hline $\begin{array}{l}\text { Pseudomonas fragi, Pseudomonas simiae, } \\
\text { Clostridium vincentii, Pseudomonas } \\
\text { jessenii and Iodobacter fluviatilis }\end{array}$ & bacteria & PCR-DGGE fingerprint & Xie et al. (2017) \\
\hline $\begin{array}{l}\text { Bacillus licheniformis, Cellvibrio mixtus } \\
\text { subsp. mixtus, Bacillus tequilensis, } \\
\text { Clostridium populeti, and Clostridium } \\
\text { xylanolyticum. }\end{array}$ & bacteria & PCR-DGGE gels & Yu et al. (2019) \\
\hline
\end{tabular}


crobes. For example, Saludes et al. (2007) applied the oxygen uptake rate (OUR) and the adenosine triphosphate (ATP) bioluminescence technique to measure the microbial activity and total active microbial biomass during the composting. Still, this approach was limited, with a lack of functions about the microbial community evaluation; also, the secondary metabolites were challenging to measure (Awasthi et al. 2019). Then, molecular analysis approaches, such as the use of DNA and RNA, make the compost microbial analyses more accessible and more economical (Jurado et al. 2014; Awasthi et al. 2019).

The primary purpose of investigating the microbial communities is to understand their function during the composting process (Awasthi et al. 2019) under cold conditions. It was reported that different composting formulations, methods, and time have different effects on microbial community structure (Tian et al. 2017). To classify the microbial communities and their dynamics throughout the composting (Awasthi et al. 2018), the molecular

$\mathrm{T}$ a b 1 e 4

Summary of literature reports on various compost maturity indices of different sources

\begin{tabular}{|c|c|c|c|}
\hline Index & Parameter & Maturity test & Reference \\
\hline Physical & $\begin{array}{l}\text { Odour, colour, temperature, } \\
\text { particle size and inert materials }\end{array}$ & ------ & $\begin{array}{l}\text { Bernal et al. (2009); Onwosi et al. } \\
(2017)\end{array}$ \\
\hline \multirow{7}{*}{ Chemical } & Carbon and nitrogen analyses & $\mathrm{C} / \mathrm{N}$ ratio in solid and water extract & $\begin{array}{l}\text { Bernal et al. (2009); Onwosi et al. } \\
(2017)\end{array}$ \\
\hline & Cation exchange capacity & $\mathrm{CEC}, \mathrm{CEC} /$ total organic- $\mathrm{C}$ ratio, etc. & $\begin{array}{l}\text { Bernal et al. (2009); Onwosi et al. } \\
\text { (2017) }\end{array}$ \\
\hline & Water-soluble extract & $\mathrm{pH}, \mathrm{EC}$, organic-C, ions, etc. & $\begin{array}{l}\text { Bernal et al. (2009); Onwosi et al. } \\
(2017)\end{array}$ \\
\hline & Mineral nitrogen & $\mathrm{NH}_{4}-\mathrm{N}$ content, $\mathrm{NH}_{4}-\mathrm{N} / \mathrm{NO}_{3}-\mathrm{N}$ ratio & Cerda et al.(2018) \\
\hline & Pollutants & Heavy metals and organics. & Bernal et al. (2009) \\
\hline & Organic matter quality, & $\begin{array}{l}\text { Organic composition: lignin, } \\
\text { complex carbohydrates, lipids, } \\
\text { sugars, etc. }\end{array}$ & Fourti(2013) \\
\hline & Humification & $\begin{array}{l}\text { Humification indices and humic- } \\
\text { like substances characterization: } \\
\text { elemental and functional group } \\
\text { analyses, molecular weight } \\
\text { distribution, } \mathrm{E}_{4} / \mathrm{E}_{6} \text { ratio, pyrolysis } \\
\text { GC-MS, spectroscopic studies (NMR } \\
\text { and FTIR, Fluorescence, etc.), etc. }\end{array}$ & $\begin{array}{l}\text { Bernal et al. (2009); Onwosi et al. } \\
(2017)\end{array}$ \\
\hline \multirow[t]{3}{*}{ Biological } & Microbial activity indicators & $\begin{array}{l}\text { Respiration }\left(\mathrm{O}_{2} \text { uptake/consumption, }\right. \\
\mathrm{CO}_{2} \text { production, self-heating test, } \\
\text { biodegradable constituents) } \\
\text { Enzyme activity (phosphatases, } \\
\text { dehydrogenases, proteases, etc.) } \\
\text { ATP content } \\
\text { Nitrogen mineralization- } \\
\text { immobilization potential, } \\
\text { nitrification, etc. } \\
\text { Microbial biomass }\end{array}$ & $\begin{array}{l}\text { Fourti (2013); Bernal et al. (2009); } \\
\text { Onwosi et al. (2017) }\end{array}$ \\
\hline & Phytotoxicity & Germination and plant growth tests & Waqas et al. (2019) \\
\hline & Others & $\begin{array}{l}\text { Viable weed seed, pathogen and } \\
\text { ecotoxicity tests }\end{array}$ & Bernal et al. (2009) \\
\hline
\end{tabular}


biology, biological tools, and the whole sequence and community diversity of microorganisms were studied (Awasthi et al. 2019). Based on the research progress, many isolation techniques were used to identify compost microbial communities such as PCR-DGGE, cloning, and sequencing (Awasthi et al. 2018). Compared with the traditional DNA sequencing technology, high-throughput sequencing improves the ability to discover new functional genes and unknown microbial sequences, leading to a more comprehensive understanding of microbial diversity in the composting (Hou et al. 2017; Tian et al. 2017; Awasthi et al. 2018). These methods provide a complete and simple way to comprehend the whole composting process (Awasthi et al. 2019) in cold areas.

\section{COMPOST QUALITY ASSESSMENT IN COLD REGIONS}

\subsection{Maturity and stability indices}

In cold regions, the composting period and composting quality are essential factors that affect the economic benefits of the composting process (Kianirad et al. 2009). The maturity of compost can be defined as the degree of completion of the composting process, which can be quantified by the degree of formation of humus in the final compost product (Onwosi et al. 2017). The beneficial effects of compost products on the physical, chemical, and biological properties of soil and the effectiveness of the nutrient sources depend on the maturity of the final compost product (Bernal et al. 2009). The stability of compost products is a step in the decomposition of carbon-based materials, which is inextricably linked to biological patterns (Cerda et al. 2018). Specific compost maturity analyses focus on the chemical and physical parameters of compost products (Wang et al. 2004; Cerda et al. 2018). The nitrogen index (NI) is an essential indicator of compost maturity. It may be the ratio between $\mathrm{NH}_{4}^{+}$and $\mathrm{NO}_{3}^{-}$. A NI value of less than 0.5 indicates that the compost has not been sufficiently improved, while up to 3.0 indicates that the compost has been enhanced (Awasthi et al. 2019). Unfortunately, tests of compost products such as TN or total carbon have long been considered inadequate to predict plant growth responses for all types of compost products (Wang et al. 2004; Cerda et al. 2018). Nevertheless, recently, biological and chemical parameters have arisen as suitable indicators both during and at the end of the composting processes (Cerda et al. 2018), as summarized in Table 4, the physical characteristics of colour, odour, and temperature give a general concept of the decomposition stage. Still, little information about compost maturity is provided (Bernal et al. 2009). Chemical methods are widely used, including the measurement of $\mathrm{C} / \mathrm{N}$ ratio in compost mixture (Cerda et al. 2018; Onwosi et al. 2017), and in the water extract, water-soluble organic-C, the water-soluble organic-C/total organic-N ratio (Cerda et al. 2018; Bernal et al. 2009; Onwosi et al. 2017). Many authors use different indexes and parameters to evaluate compost maturity (Onwosi et al. 2017).

Concisely, compost maturity is not described by one parameter; it can be evaluated by measuring two or more parameters of the final compost product. An investigation is continuing for the initiation of internationally accepted and unified indices to determine compost maturity (Onwosi et al. 2017).

\section{CONCLUSIONS}

Composting is a precious process in livestock manure management in cold areas because of its strength and the opportunity to obtain useful compost final products. General challenges in manure composting and the strategies used to accomplish the composting process in cold regions were summarized. In addition, the composting monitoring challenges and the microbiology in livestock manure composting under cold conditions were evaluated. Moreover, the compost quality assessments in cold regions were reviewed. Still, research is required to understand the enhancement mechanism and the interactions of the additives materials with the predominant cold-active microorganisms to enhance the composting process under cold conditions. It is in this light that this review is expected to help researchers understand the strengthening mechanism and interaction between additives and dominant microorganisms to heighten our managing skills within the composting system in cold regions. 
Acknowledgement: The Natural Science Foundation of China (Grant no. 41771559) supported this work.

\section{REFERENCES}

AKDENIZ, N. 2019. A systematic review of biochar use in animal waste composting. In Waste Management, vol. 88 , pp. 291-300. DOI: 10.1016/j.wasman.2019.03.054.

AWASTHI, M.K. - CHEN, H. - WANG, Q. - LIU, T. - DUAN, Y. - AWASTHI, S.K. - ZHANG, Z. 2018. Succession of bacteria diversity in the poultry manure composted mixed with clay: Studies upon its dynamics and associations with physicochemical and gaseous parameters. In Bioresource Technology, vol. 267, pp. 618-625. DOI: 10.1016/j. biortech.2018.07.094.

AWASTHI, S.K. - SARSAIYA, S. - AWASTHI, M.K. - LIU, T. - ZHAO, J. - KUMAR, S. - ZHANG, Z. 2019. Changes in global trends in food waste composting: Research challenges and opportunities. In Bioresource Technology, vol. 299. DOI: 10.1016/j.biortech.2019.122555.

BEFFA, T. - BLANC, M. - MARILLEY, L. - FISCHER, J.L. - LYON, P.-F. - ARAGNO, M. 1996. Taxonomic and metabolic microbial diversity during composting. In The Science of Composting, pp. 149-161. DOI: 10.1007/978-94-0091569-5_16.

BERNAL, M. - ALBURQUERQUE, J. - MORAL, R. 2009 Composting of animal manure and chemical criteria for compost maturity assessment. A review. In Bioresource Technology, vol. 100, no. 22, pp. 5444-5453. DOI: 10.1016/j.biortech.2008.11.027.

BLINNIKOV, MS. 2011. A geography of Russia and its neighbours. New York, USA : Guilford Press. 448 p. ISBN 9781606239209.

BOGAARD, A. - FRASER, R. - HEATON, T.H.E. - WALLACE, M. - VAIGLOVA, P. - CHARLES, M. - JONES, G. - EVERSHED, R.P. - STYRING, A.K. - ANDERSEN, N.H. - ARBOGAST, R. - BARTOSIEWICZ, L. - GARDEISEN, A. - KANSTRUP, M. - MAIER, U. - MARINOVA, E. - NINOV, L. - SCHÄFER, M. - STEPHAN, E. 2013. Crop manuring and intensive land management by Europe's first farmers. In Proceedings of the National Academy of Sciences of the United States of America, vol. 110, pp.12589-12594.

BUCCHIGNANI, E. - MONTESARCHIO, M. - CATTANEO, L. - MANZI, M.P. - MERCOGLIANO, P. 2014. Regional climate modelling over China with COSMO-CLM: Performance assessment and climate projections. In Journal of Geophysical Research: Atmospheres, vol. 119, no. 21. DOI: 10.1002/2014jd022219.

CERDA, A. - ARTOLA, A. - FONT, X. - BARRENA, R. - GEA, T. - SÁNCHEZ, A. 2018. Composting of food wastes: Status and challenges. In Bioresource Technology, vol. 248, pp. 57-67. DOI: 10.1016/j.biortech.2017.06.133.

CHAUDHARY, D.K. - KIM, J. 2019. New insights into bioremediation strategies for oil-contaminated soil in cold environments. In International Biodeterioration \& Biodegradation, vol. 142, pp. 58-72. DOI: 10.1016/j. ibiod.2019.05.001.

CUI, H.-Y. - ZHANG, S.-B. - ZHAO, M.-Y. - ZHAO, Y. WEI, Z.-M. 2020. Parallel faction analysis combined with two-dimensional correlation spectroscopy reveal the characteristics of mercury-composting-derived dissolved organic matter interactions. In Journal of Hazardous Materials, vol. 384, 121395. DOI: 10.1016/j.jhazmat.2019.121395.

CZEKAŁA, W. - MALIŃSKA, K. - CÁCERES, R. JANCZAK, D. - DACH, J. - LEWICKI, A. 2016. Co-composting of poultry manure mixtures amended with biochar - The effect of biochar on temperature and $\mathrm{C}-\mathrm{CO}_{2}$ emission. In Bioresource Technology, vol. 200, pp. 921-927. DOI: 10.1016/j.biortech.2015.11.019.

DABNEY, S.M. - DELGADO, J.A. - REEVES, D.W. 2001. Using winter cover crops to improve soil and water quality. In Communication in Soil Science and Plant Analysis, vol. 32, no. $7-8$, pp. 1221-1250. DOI: $10.1081 /$ css100104110.

EL-NAGGAR, A. - LEE, S.S. - RINKLEBE, J. - FAROOQ, M. - SONG, H. - SARMAH, A.K. - OK, Y.S. 2019. Biochar application to low fertility soils: A review of current status, and future prospects. In Geoderma, vol. 337, pp. 536-554. DOI: 10.1016/j.geoderma.2018.09.034.

ENGLER, C.R. - JORDAN, E.R. - MCFARLAND, M.J. LACEWELL, R.D.1999. Economics and environmental impact of biogas production as a manure management strategy. In Texas Aanimal Manure Management Conference : proceedings. College Station, TX, USA: Texas A \& M University.

FOURTI, O. 2013. The maturity tests during the composting of municipal solid wastes. In Resources Conservation and Recycling, vol. 72, pp. 43-49. DOI: 10.1016/j.resconrec.2012.12.001

GOU, C. - WANG, Y. - ZHANG, X. - LOU, Y. - GAO, Y. 2017. Inoculation with a psychrotrophic-thermophilic complex microbial agent accelerates onset and promotes maturity of dairy manure-rice straw composting under cold climate conditions. In Bioresource Technology, vol. 243, pp. 339-346. DOI: 10.1016/j.biortech.2017.06.097.

GUO, X.-X. - LIU, H.-T. - ZHANG, J. 2020. The role of biochar in organic waste composting and soil improvement: A review. In Waste Management, vol. 102, pp. 884-899. DOI: 10.1016/j.wasman.2019.12.003.

HE, Z. - PAGLIARI, P.H. - WALDRIP, H.M. 2016. Applied and environmental chemistry of animal manure: A Review. In Pedosphere, vol. 26, no. 6, pp. 779-816. DOI: 10.1016/ s1002-0160(15)60087-x.

HORN, H.V. - WILKIE, A. - POWERS, W. - NORDSTEDT, R. 1994. Components of dairy manure management Systems. In Journal of Dairy Science, vol. 77, no. 7, pp. 2008-2030. DOI: 10.3168/jds.s0022-0302 (94)77147-2.

HOU, N. - WEN, L. - CAO, H. - LIU, K. - AN, X. - LI, D. LI, C. 2017. Role of psychrotrophic bacteria in organic domestic waste composting in cold regions of China. In Bioresource Technology, vol. 236, pp. 20-28. DOI: 10.1016/j. biortech.2017.03.166.

HU, Y. - CHENG, H. - TAO, S. 2017. Environmental and human health challenges of industrial livestock and poultry farming in China and their mitigation. In Environment International, vol. 107, pp. 111-130. DOI: 10.1016/j.envint.2017.07.003.

JIANG, J. - LIU, X. - HUANG, Y. - HUANG, H. 2015. Inoculation with nitrogen turnover bacterial agent appropriately increasing nitrogen and promoting maturity in pig manure composting. In Waste Management, vol. 39, pp. 78-85. DOI: 10.1016/j.wasman.2015.02.025.

JURADO, M. - LÓPEZ, M.J. - SUÁREZ-ESTRELLA, F. VARGAS-GARCÍA, M.C. - LÓPEZ-GONZÁLEZ, J.A. - MORENO, J. 2014. Exploiting composting biodiversity: Study of the persistent and biotechnologically relevant microorganisms from lignocellulose-based composting. In Bioresource Technology, vol. 162, pp. 283-293. DOI: 10.1016/j.biortech.2014.03.145. 
KIANIRAD, M. - MUAZARDALAN, M. - SAVAGHEBI, G. - FARAHBAKHSH, M. - MIRDAMADI, S. 2009. Effects of temperature treatment on corncob composting and reducing of composting time: a comparative study. In Waste Management \& Research, vol. 28, no. 10, pp. 882-887. DOI: $10.1177 / 0734242 \times 09342359$.

KOVÁČIK, P. - KOZÁNEK, M. - TAKÁČ, P. - GALLIKOVÁ, M. - VARGA, L. 2010. The effect of pig manure fermented by larvae of houseflies on the yield parameters of sunflowers (Helinthus annul L.). In Acta Universitatis Agriculturae et Silviculturae Mendelianae Brunensis, vol. LVIII (58), no. 2, pp. $147-153$.

KOVÁCIK, P. - ŽOFAJOVÁ, A. - ŠIMANSKÝ, V. HALÁSZOVÁ, K. 2016. Spring barley yield parameters after lignite, sodium humate and nitrogen utilization. In $A g-$ riculture (Polnohospodárstvo), vol. 62, no. 3, pp. 80-89. DOI: 10.1515/agri-2016-0009.

LI, H. - LU, J. - ZHANG, Y. - LIU, Z. 2018. Hydrothermal liquefaction of typical livestock manure in China: Biocrude oil production and migration of heavy metals. In Journal of Analytical and Applied Pyrolysis, vol. 135, pp. 133-140. DOI: 10.1016/j.jaap.2018.09.010.

LI, J. - BAO, H. - XING, W. - YANG, J. - LIU, R. - WANG, X. - WU, F. 2019. Succession of fungal dynamics and their influence on physicochemical parameters during pig manure composting employing with pine leaf biochar. In Bioresource Technology, vol. 297, 122377. DOI: 10.1016/j. biortech.2019.122377.

LI, S.Q. - YAN, L. - XU, J.G. - LIU, D.Y. 2012. Nitrogen transformation during pig manure composting at low temperature. In Advanced Material Research, vol. 433-440, pp. 1226-1231. DOI: 10.4028/www.scientific.net/amr.433440.1226 .

LIU, H. - WANG, L. - LEI, M. 2019. Positive impact of biochar amendment on thermal balance during swine manure composting at relatively low ambient temperature. In Bioresource Technology, vol. 273, pp. 25-33. DOI: 10.1016/j. biortech.2018.10.033

LIU, L. - WANG, S. - GUO, X. - ZHAO, T. - ZHANG, B. 2018. Succession and diversity of microorganisms and their association with physicochemical properties during green waste thermophilic composting. In Waste Management, vol. 73, pp. 101-112. DOI: 10.1016/j.wasman.2017.12.026.

LOYON, L. 2017. Overview of manure treatment in France. In Waste Management, vol. 61, pp. 516-520. DOI: 10.1016/j. wasman.2016.11.040.

MAAYER, P.D. - ANDERSON, D. - CARY, C. - COWAN, D.A. 2014. Some like it cold: understanding the survival strategies of psychrophiles. In EMBO Reports, vol. 15, no. 5, pp. 508-517. DOI: $10.1002 / \mathrm{embr} .201338170$.

MARGESIN, R. - CIMADOM, J. - SCHINNER, F. 2006 Biological activity during composting of sewage sludge at low temperatures. In International Biodeterioration \& Biodegradation, vol. 57, no. 2, pp. 88-92. DOI: 10.1016/j. ibiod.2005.12.001.

MASSÉ, D.I. - MASSE, L. 2001. The effect of temperature on slaughterhouse wastewater treatment in anaerobic sequencing batch reactors. In Bioresource Technology, vol. 76, no. 2, pp. 91 -98. DOI: 10.1016/s0960-8524(00)00105-x.

MINOBE, S. - KUWANO-YOSHIDA, A. - KOMORI, N. - XIE, S.-P. - SMALL, R.J. 2008. Influence of the Gulf Stream on the troposphere. In Nature, vol. 452, no. 7184, pp. 206-209. DOI: 10.1038/nature06690.

NAKAMURA, K. - HARUTA, S. - NGUYEN, H.L. - ISHII, M. - IGARASHI, Y. 2004. Enzyme production-based approach for determining the functions of microorganisms within a community. In Applied and Environmental Mi- crobiology, vol. 70 , no. 6 , pp. $3329-3337$. DOI: $10.1128 /$ aem.70.6.3329-3337.2004.

ONWOSI, C.O. - IGBOKWE, V.C. - ODIMBA, J.N. - EKE, I.E. - NWANKWOALA, M.O. - IROH, I.N. - EZEOGU, L.I. 2017. Composting technology in waste stabilization: On the methods, challenges and future prospects. In Journal of Environmental Management, vol. 190, pp. 140-157. DOI: $10.1016 /$ j.jenvman.2016.12.051.

PHILIPPE, F.-X. - NICKS, B. 2015. Review on greenhouse gas emissions from pig houses: Production of carbon dioxide, methane and nitrous oxide by animals and manure. In $\mathrm{Ag}$ riculture, Ecosystem \& Environment, vol. 199, pp. 10-25. DOI: 10.1016/j.agee.2014.08.015.

PRATT, C. - REDDING, M. - HILL, J. - MUDGE, S.R. WESTERMANN, M. - PAUNGFOO-LONHIENNE, C. SCHMIDT, S. 2014. Assessing refrigerating and freezing effects on the biological/chemical composition of two livestock manure. In Agriculture, Ecosystem \& Environment, vol. 197, pp. 288-292. DOI: 10.1016/j.agee.2014.08.012.

REYES-TORRES, M. - OVIEDO-OCAÑA, E. - DOMINGUEZ, I. - KOMILIS, D. - SÁNCHEZ, A. 2018. A systematic review on the composting of green waste: Feedstock quality and optimization strategies. In Waste Management, vol. 77, pp. 486-499. DOI: 10.1016/j.wasman.2018.04.037.

RICO, C. - GARCÍA, H. - RICO, J. 2011. Physical-anaerobic-chemical process for treatment of dairy cattle manure. In Bioresource Technology, vol. 102, no. 3, pp. 2143-2150. DOI: 10.1016/j.biortech.2010.10.068.

RYCKEBOER, J. - MERGAERT, J. - COOSEMANS, J. - DEPRINS, K. - SWINGS, J. 2003. Microbiological aspects of biowaste during composting in monitored compost bin. In Journal of Applied Microbiology, vol. 94, no. 1, pp. 127-137. DOI: 10.1046/j.1365-2672.2003.01800.x.

SAADY, N.M.C. - MASSÉ, D.I. 2013. Psychrophilic anaerobic digestion of lignocellulosic biomass: A characterization study. In Bioresource Technology, vol. 142, pp. 663-671. DOI: 10.1016/j.biortech.2013.05.089.

SALUDES, R. - IWABUCHI, K. - KAYANUMA, A. - SHIGA, T. 2007. Composting of dairy cattle manure using a thermophilic-mesophilic sequence. In Biosystems Engineering, vol. 98 , no. 2, pp. 198-205. DOI: 10.1016/j.biosystemseng.2007.07.003.

SÁNCHEZ, Ó.J. - OSPINA, D.A. - MONTOYA, S. 2017. Compost supplementation with nutrients and microorganisms in composting process. In Waste Management, vol. 69, pp. 136-153. DOI: 10.1016/j.wasman.2017.08.012.

SANCHEZ-MONEDERO, M. - CAYUELA, M. - ROIG, A. - JINDO, K. - MONDINI, C. - BOLAN, N. 2018. Role of biochar as an additive in organic waste composting. In Bioresource Technology, vol. 247, pp. 1155-1164. DOI: 10.1016/j.biortech.2017.09.193.

STEMPVOORT, D.V. - BIGGAR, K. 2008. Potential for bioremediation of petroleum hydrocarbons in groundwater under cold climate conditions: A review. In Cold Regions Science and Technology, vol. 53, no. 1, pp. 16-41. DOI: 10.1016/j. coldregions.2007.06.009.

SUBBOTIN, I. - BRIUKHANOV, A. - VASILEV, E. 2017. Factor analysis of environmental impact of manure utilization. In Engineering for Rural Development : Proceeding from 16. International Conference, pp. 625-629. DOI: 10.22616/erdev2017.16.n124.

SUN, Q. - CHEN, J. - WEI, Y. - ZHAO, Y. - WEI, Z. ZHANG, H. - XIE, X. 2019. Effect of semi-continuous replacements of compost materials after inoculation on the performance of heat preservation of low temperature composting. In Bioresource Technology, vol. 279, pp. 50-56. DOI: 10.1016/j.biortech.2019.01.090. 
SUN, Q. - WU, D. - ZHANG, Z. - ZHAO, Y. - XIE, X. - WU, J. - WEI, Z. 2017. Effect of cold-adapted microbial agent inoculation on enzyme activities during composting startup at low temperature. In Bioresource Technology, vol. 244, pp. 635-640. DOI: 10.1016/j.biortech.2017.08.010.

TIAN, X. - YANG, T. - HE, J. - CHU, Q. - JIA, X. - HUANG, J. 2017. Fungal community and cellulose-degrading genes in the composting process of Chinese medicinal herbal residues. In Bioresource Technology, vol. 241, pp. 374-383. DOI: $10.1016 /$ j.biortech.2017.05.116.

TRAN, Q.N.M. - MIMOTO, H. - NAKASAKI, K. 2015. Inoculation of lactic acid bacterium accelerates organic matter degradation during composting. In International Biodeterioration \& Biodegradation, vol. 104, pp. 377-383. DOI: 10.1016/j.ibiod.2015.07.007.

WANG, K. - LI, W. - LI, Y. - GONG, X. - WU, C. - REN, N. 2013. The modelling of combined strategies to achieve thermophilic composting of sludge in cold region. In International Biodeterioration \& Biodegradation, vol. 85, pp. 608-616. DOI: 10.1016/j.ibiod.2013.03.005.

WANG, L. - WANG, L. - WANG, D. - LI, J. 2013. Isolation and application of thermophilic and psychrophilic microorganisms in the composting process. In Waste and Biomass Valorization, vol. 5, no. 3, pp. 433-440. DOI: 10.1007/ s12649-013-9253-8.

WANG, P. - CHANGA, C. - WATSON, M. - DICK, W. CHEN, Y. - HOITINK, H. 2004. Maturity indices for composted dairy and pig manure. In Soil Biology \& Biochemistry, vol. 36, no. 5, pp. 767-776. DOI: 10.1016/j.soilbio.2003.12.012.

WANG, X. - HELGASON, B. - WESTBROOK, C. - BEDARD-HAUGHN, A. 2016. Effect of mineral sediments on carbon mineralization, organic matter composition and microbial community dynamics in a mountain peatland. In Soil Biology \& Biochemistry, vol. 103, pp. 16-27. DOI: 10.1016/j.soilbio.2016.07.025.

WAQAS, M. - NIZAMI, A. - ABURIAZAIZA, A. BARAKAT, M. - ASAM, Z. - KHATTAK, B. - RASHID, M. 2019. Untapped potential of zeolites in optimization of food waste composting. In Journal of Environmental Management, vol. 241, pp. 99-112. DOI: 10.1016/j.jenvman.2019.04.014.

WEI, L. - SHUTAO, W. - JIN, Z. - TONG, X. 2014. Biochar influences the microbial community structure during tomato stalk composting with chicken manure. In Bioresource Technology, vol. 154, pp. 148-154. DOI: 10.1016/j. biortech.2013.12.022.

WEI, Y. - LI, J. - SHI, D. - LIU, G. - ZHAO, Y. - SHIMAOKA, T. 2017. Environmental challenges impeding the composting of biodegradable municipal solid waste: A critical review. In Resource, Conservation \& Recycling, vol. 122, pp. 51-65. DOI: 10.1016/j.resconrec.2017.01.024.

WEI, Y. - ZHAO, Y. - ZHAO, X. - GAO, X. - ZHENG, Y. - ZUO, H. - WEI, Z. 2020. Roles of different humin and heavy-metal resistant bacteria from composting on heavy metal removal. In Bioresource Technology, vol. 296, 122375. DOI: 10.1016/j.biortech.2019.122375.

WEI, Z. - XI, B. - ZHAO, Y. - WANG, S. - LIU, H. - JIANG, Y. 2007. Effect of inoculating microbes in municipal solid waste composting on characteristics of humic acid. In Chemosphere, vol. 68, no. 2, pp. $368-374$. DOI: $10.1016 / \mathrm{j}$. chemosphere.2006.12.067.

WILLIAMS, R.T. - MARKS, P.J. 1991. Optimization of composting for explosives contaminated soil. Final Report. CETHA-TS-CR-91053. Washington DC : U.S. Army Corps of Engineers.

XI, B. - ZHAO, X. - HE, X. - HUANG, C. - TAN, W. - GAO,
R. - LI, D. 2016. Successions and diversity of humic-reducing microorganisms and their association with physical-chemical parameters during composting. In Bioresource Technolology, vol. 219, pp. 204-211. DOI: 10.1016/j. biortech.2016.07.120.

XIAO, R. - AWASTHI, M.K. - LI, R. - PARK, J. - PENSKY, S.M. - WANG, Q. - ZHANG, Z. 2017. Recent developments in biochar utilization as an additive in organic solid waste composting: A review. In Bioresource Technology, vol. 246, pp. 203-213. DOI: 10.1016/j.biortech.2017.07.090.

XIE, X.-Y. - ZHAO, Y. - SUN, Q.-H. - WANG, X.-Q. - CUI, H.-Y. - ZHANG, X. - WEI, Z.-M. 2017. A novel method for contributing to composting start-up at low temperature by inoculating cold-adapted microbial consortium. In Bioresource Technology, vol. 238, pp. 39-47. DOI: 10.1016/j. biortech.2017.04.036

XU, Z. - WU, H. - WU, M. 2010. Energy performance and consumption for biogas heat pump air conditioner. In Energy, vol. 35, no. 12, pp. 5497-5502. DOI: 10.1016/j.energy.2010.01.040.

YAO, Y. - HUANG, G. - AN, C. - CHEN, X. - ZHANG, P. - XIN, X. - AGNEW, J. 2019. Anaerobic digestion of livestock manure in cold regions: Technological advancements and global impacts. In Renewable and Sustainable Energy Reviews, vol. 119, 109494. DOI: 10.1016/j. rser.2019.109494.

YAO, Y. - HUANG, G.H. - AN, C.J. - CHENG, G.H. - WEI, J. 2017. Effects of freeze-thawing cycles on desorption behaviors of PAH-contaminated soil in the presence of a biosurfactant: a case study in western Canada. In Environtal Science: Processes \& Impacts, vol. 19, no. 6, pp. 874-882. DOI: $10.1039 / \mathrm{c} 7 \mathrm{em} 00084 \mathrm{~g}$.

YU, X.-F. - BORJIGIN, Q. - GAO, J.-L. - WANG, Z.-G. HU, S.-P. - BORJIGIN, N. - HAN, S.-C. 2019. Exploration of the key microbes and composition stability of microbial consortium GF-20 with efficiently decomposes corn stover at low temperatures. In Journal of Integrative Agriculture, vol. 18 , no. 8, pp. 1893 -1904. DOI: 10.1016/s20953119(19)62609-2.

ZHANG, C. - XU, Y. - ZHAO, M. - RONG, H. - ZHANG, K. 2018. Influence of inoculating white-rot fungi on organic matter transformations and mobility of heavy metals in sewage sludge based composting. In Journal of Hazardous Material, vol. 344, pp. 163-168. DOI: 10.1016/j. jhazmat.2017.10.01.7.

ZHU, L. - WEI, Z. - YANG, T. - ZHAO, X. - DANG, Q. CHEN, X. - ZHAO, Y. 2020. Core microorganisms promote the transformation of DOM fractions with different molecular weights to improve the stability during composting. In Bioresource Technology, vol. 299, 122575. DOI: 10.1016/j.biortech.2019.122575.

ZUBAIR, M. - WANG, S. - ZHANG, P. - YE, J. - LIANG, J. NABI, M. - CAI, Y. 2020. Biological nutrient removal and recovery from solid and liquid livestock manure: Recent advance and perspective. In Bioresource Technology, vol. 301, 122823. DOI: $10.1016 /$ j.biortech.2020.122823.

Received: January 29, 2020 Accepted: March 23, 2020 